\title{
NURSE EDUCATORS' PERCEPTIONS ON FACILITATING REFLECTIVE THINKING IN CLINICAL NURSING EDUCATION
}

\author{
Mary Chabeli \\ DCur \\ Professor, Department of Nursing Science, Rand Afrikaans University \\ Corresponding author: mch@edcur.rau.ac.za
}

\author{
Marie Muller \\ DCur \\ Professor of Nursing; Dean of Faculty of Education and Nursing, Rand Afrikaans University
}

Keywords: Nurse educator; facilitating reflective thinking; clinical nursing education; awareness and disequilibrium phase; interactive constructing process and consolidation phase

\begin{abstract}
This article seeks to publish the results of nurse educators with regard to how reflective thinking of learners can be facilitated in clinical nursing education. The results were obtained through a perception survey using an agenda focus group in the second phase of an original study whose aim was to develop a model to facilitate reflective thinking in clinical nursing education. A qualitative, exploratory and descriptive study, which was contextual in nature, was conducted. A concept analysis of reflective thinking was conducted based on the principles described by Wilson (1963:23-39) and Gift (1997:75-76). These results (unpublished) were used to guide the perception survey of nurse educators on how reflective thinking can be facilitated in clinical nursing education. An 'etic' approach to qualitative data analysis was used (Morse, 1994:166-167), and categories were placed in the matrices as described by Miles \& Huberman (1994:241-243). The results revealed empowerment of the learner through different teaching strategies, assessment and evaluation methods, and the supporting attitudes in accordance with the three phases of the reflective thinking process. Trustworthiness was assured by adhering to Lincoln and Guba's (1985:290) principles such as credibility, transferability, confirmability and dependability. It is recommended that a model to facilitate reflective thinking in clinical nursing education be developed with guidelines to assist nurse educators with the implementation of the model.
\end{abstract}

\section{OPSOMMING}

Hierdie artikel beoog om die resultate van verpleegopvoeders met betrekking tot hoe reflektiewe denke van leerders in kliniese verpleegonderwys gefasiliteer kan word, te publiseer. Die resultate is bekom deur 'n persepsie-opname waar 'n agendafokusgroep in die tweede fase van 'n oorspronklike studie gebruik is, wat ten doel gehad het om ' $n$ model te ontwikkel ten einde reflektiewe denke in kliniese verpleegonderwys te fasiliteer. ' $n$ Kwalitatiewe, verkennende en beskrywende studie wat kontekstueel van aard is, is uitgevoer. ' $n$ Konsepontleding van reflektiewe denke is uitgevoer op grond van die beginsels wat deur Wilson (1963;23-29) en Gift (1997:75-76) beskryf is. Hierdie resultate (ongepubliseer) is gebruik om die persepsie-opname van verpleegopvoeders oor hoe reflektiewe denke in kliniese verpleegonderwys gefasiliteer kan word, te rig. ' $n$ 'Buite-teoretiese' benadering tot kwalitatiewe data-ontleding is gebruik (Morse, 1994:166-167) en kategorieë is in matrikse geplaas wat deur Miles en Huberman (1994:21-243) beskryf word. Die resultate het bemagtiging van die leerder deur verskillende onderrigstrategieë, assesserings- en evalueringsmetodes en die ondersteunende gesindhede in ooreenstemming met die drie fases van die reflektiewe denkproses aan die lig gebring. Betroubaarheid is verseker deur Lincoln en Guba (1955:290) se beginsels, soos geloofwaardigheid, oordraagbaarheid, bevestigbaarheid en betroubaarheid, na te volg. Daar word aanbeveel dat ' $n$ model om reflektiewe denke in kliniese verpleegonderwys te fasiliteer ontwikkel word met riglyne om verpleegopvoeders met die implementering van die model te help. 


\section{INTRODUCTION}

Much has been researched as to what critical and reflective thinking are, but how these higher order thinking skills can be facilitated especially in clinical nursing education, is not addressed. The nursing profession is challenged with the provision of quality assurance in its education and training system and the production of graduates in line with the best practices to meet international standards (National Plan for Higher Education, 2001). Central to quality nursing education is reflective thinking facilitated by learner-centered teaching strategies and evaluation methods that foster collaborative interaction and sharing of ideas and feelings (Van der Horst \& McDonald, 1997:127).

Facilitating reflective thinking is the heart of outcomesbased education (Van der Horst \& McDonald, 1997:5, 144) since all educational programmes should provide a balanced view by developing the learners' critical and reflective abilities in making rational clinical decisions and solving problems, that is 'fitness for purpose'. Clinical nursing education is a dynamic, constantly changing, real-life environment where learners are able to marry the theoretical component with practice. Lindsey and Hartrick (1996:107) argue that clinical nursing education requires nurses to truly reflect on the promotion of health and healing. The focus in facilitating reflective thinking should be on learners providing evidential reasoning, justifying their actions, making rational interpretations, deductive inference, weighing evidence and distinguishing between weak and strong arguments in the process of decision-making and solving problems (Miller, 1992:1406). Reflective thinking is a composite of knowledge, skills, attitude and values where, in nursing, a comprehensive and holistic approach to clinical nursing education is imperative, and facilitating reflective thinking becomes a vehicle to realise this aim. Nurses should strive to be reflective practitioners by developing reflective inquiry minds. They should be open- and fair-minded, be flexible, honest in facing personal biases, prudent in making judgements, willing to consider, clear about issues and orderly in complex matters (Facione, 1990:2)

The purpose of this article is to describe the results of the perception survey conducted with nurse educators regarding how reflective thinking of learners can be facilitated in clinical nursing education. Before data could be collected in this aspect, a concept analysis to clarify the meaning of reflective thinking was conducted as the first phase of an original study to develop a model to facilitate reflective thinking in clinical nursing education. The perception survey formed the second phase of the study. The results of the concept analysis provided a theoretical definition namely: Reflective thinking is a rational, progressive cyclic interactive mental process influenced by hierarchical cognitive and affective thinking skills. It is triggered by the uncertainty in a situation bringing about a state of mental awareness and disequilibrium which leads to an interactive constructing process followed by consolidation of knowledge, new insight and changed perspective as an outcome for clinical decision-making and problem solving (Chabeli, 2001:107).

The identified attributes from concept analysis that contributed to the formulation of the theoretical definition formed the three phases of reflective thinking as influenced by cognitive and affective thinking skills. Phase one is the awareness and disequilibrium phase influenced by knowledge, receptivity, comprehension and responsiveness. Phase two is the interactive constructing process influenced by analysis, values, synthesis and organisation. Phase three is concerned with consolidation of knowledge and skills to bring about new insight and a changed perspective for rational clinical decision-making and problem-solving (Figure 1).

\section{Problem statement}

In spite of the use of several teaching, assessment and evaluation methods by nurse educators in clinical nursing education, student nurses still demonstrate a lack of reflective thinking in practice as evidenced by a lack of an inquiry mind, and an inability to be reflexive and to adapt to changes for the benefit of the patient. The following research question emanates: How can reflective thinking of learners in clinical nursing education be facilitated? The objective of the study is to explore and describe the perceptions of nurse educators with regard to how reflective thinking can be facilitated in clinical nursing education.

\section{Definition of key concepts}




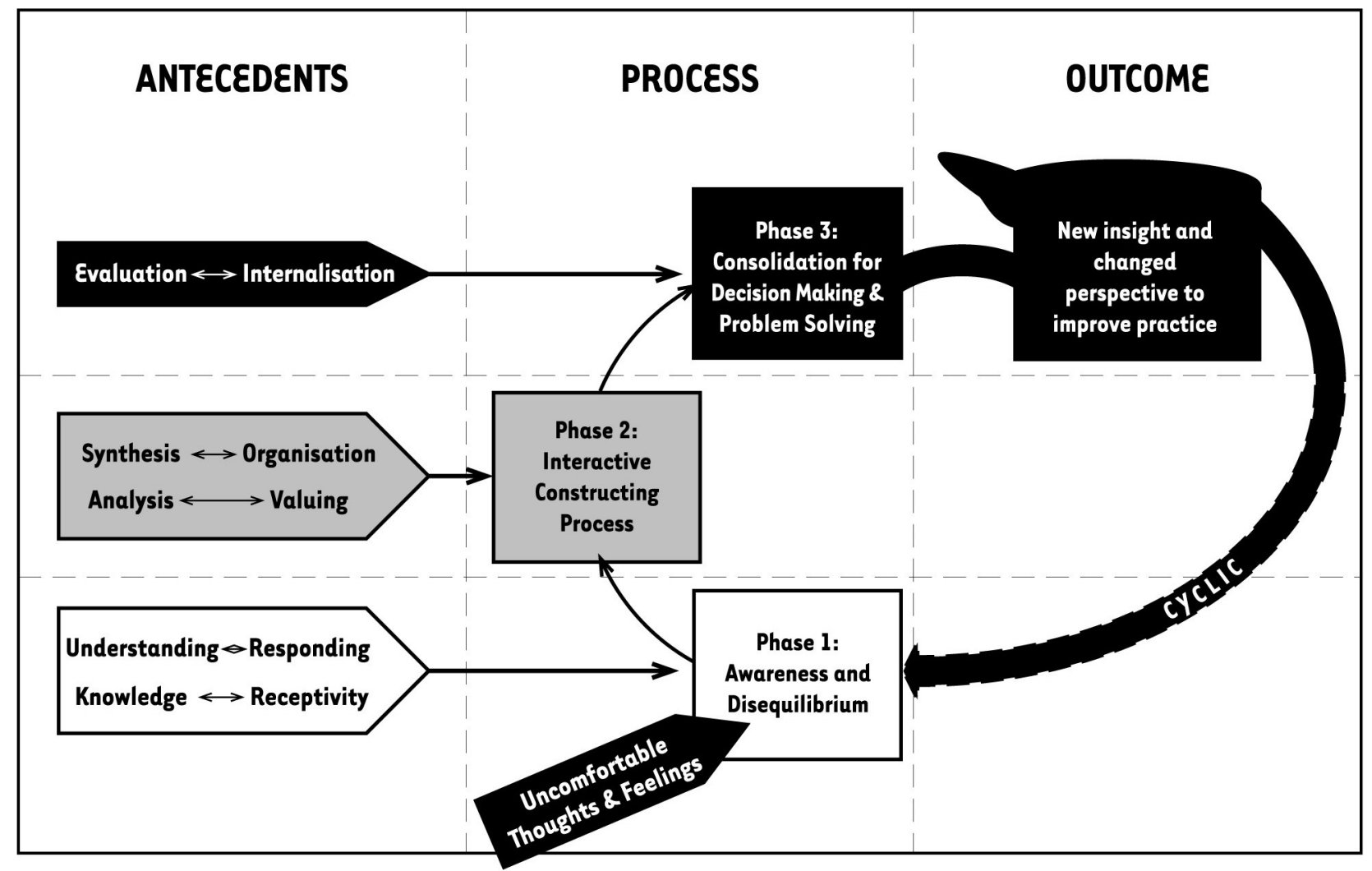

Figure1: Phases of reflective thinking in relation to cognitive and affective thinking skills as antecedents

\section{Nurse educator}

A nurse educator refers to a person who is registered with the South African Nursing Council (SANC) as a nurse educator/tutor with expert clinical competence.

\section{Facilitation of reflective thinking}

Reflective thinking involves interaction and therefore, in this study, facilitation of reflective thinking refers to a dynamic, interactive process that includes mutual and purposeful involvement between the nurse educator and the learner in clinical nursing education (Department of Nursing, RAU, 1999) with the quest to engage learners to explore knowledge and experiences leading to new understanding and appreciation.

\section{Clinical nursing education}

Clinical nursing education is a dynamic, multipurpose environment in which the theoretical component is integrated into practice. It provides the learner with meaningful, authentic and humane experience (Chabeli, 2001:150).

\section{Awareness and disequilibrium}

Awareness is a skill of recognition stimulated by insufficient knowledge and skills or any uncertainty in a given situation (Benner, Hooper-Kyriakidis \& Stannard 1999:568). Disequilibrium refers to a disturbance in search for mental balance. Piaget (in Woolfolk, 1990:46) states that if the situation does not satisfy the learner and is queer, then disequilibrium exists and the learner becomes uncomfortable due to lack of relevant knowledge of the situation.

\section{Interactive constructing process}

Interactive refers to reciprocal, mutual, correlative, interchange, exchange and interdependent (Roget, 1991:54). Constructing refers to make by fitting parts together; building; form by interpretation or explanation (Concise Oxford Dictionary, 1995). Process refers to a course of action or a procedure. It is concerned with 'what is happening in the mind, the course of action' (Concise Oxford Dictionary, 1995).

\section{Consolidation}

Consolidation refers to integration and synthesis of clinical knowledge, skills, attitude and values they have constructed with the emergence of new insight and changed perspective (Gravett, 1996:13). 


\section{Research design and method}

A qualitative, contextual, exploratory and descriptive design was used (Mouton \& Marais, 1990:43; Mouton, 1996:103-109). The design is qualitative and exploratory as a means of exploring the depth, richness and complexity inherent with regard to the perceptions of nurse educators as to how reflective thinking can be facilitated in clinical nursing education. The contextual significance of the study lies in the transformation of education in the country in general, and in clinical nursing education in particular. It is descriptive in that in-depth description of the perceptions of nurse educators, recontextualised within the existing literature, was made in order to deductively analyse the information to arrive at concluding statements that formed the basis for the description of guidelines.

Twelve nurse educators with extensive experience (ten years and more) on clinical accompaniment of basic nursing students were purposively selected to participate in the study. The purpose of the study was fully explained and consent of individual participants was obtained. Participants were assured of confidentiality and anonymity. An interactive agenda focus group interview (Krueger, 1994:6-7) was conducted for about three hours with breaks in the interim. The central question was: "How can reflective thinking of learners be facilitated in clinical nursing education in accordance with the three phases of reflective thinking as influenced by the hierarchical cognitive and affective thinking skills?".

The first session dealt with the first phase, awareness and disequilibrium influenced by knowledge, receptivity, comprehension and responsiveness. The second phase focused on how interactive constructing process influenced by analysis, values, synthesis and organisation thinking skills could be facilitated. Lastly, the third phase dealt with how consolidation of knowledge and skills for rational clinical decision-making and problem solving influenced by evaluation and internalisation thinking skills could be facilitated. Field notes were taken and a consensus discussion took place to arrive at how reflective thinking could be facilitated. An independent coder, purposively selected, was engaged in the analysis of data (Lincoln \& Guba, 1985:290).
An 'etic' approach to qualitative data analysis (Morse, 1994:166-167) was used since the data were analysed in accordance to the conceptual framework resulting from the concept analysis. Much as the existing conceptual framework was used to direct the interview, participants did not follow the levels strictly but explored the way in which they would facilitate reflective thinking in clinical nursing education as a whole. Consensus discussion among participants helped with the establishing of relevant categories. The researcher used the matrix approach described by Miles and Huberman (1994:241-243) to categorise the data meaningfully according to the phases of reflective thinking. The independent coder was given the same protocol to analyse the data meaningfully. The researcher and the external coder, held a two-hour discussion to reach an agreement on the categories and the sub-categories as to how reflective thinking can be facilitated through the three phases of reflective thinking.

A final agreement was reached as follows: the main category became the 'empowerment' of learners with reflective thinking skills. The phases of reflective thinking formed the categories. The cognitive and affective thinking skills as antecedents to reflective thinking formed the subcategories whereas the teaching strategies, assessment and evaluation methods, and the supporting attitudes formed the themes (see Table One in the matrices).

Trustworthiness was ensured by using Lincoln and Guba's principles (1985:290). Credibility was ensured by five years of prolonged engagement of the researcher in the study and the use of an expert interviewer, purposively selected to conduct the focus group. The probing of information until saturation was reached ensured credibility of the study. The triangulation of primary and secondary sources during the process of concept analysis, the conceptualisation and the use of field notes increased the credibility. Transferability was ensured by the dense description of the study to enable readers to assess the potential transferability and appropriateness for their own settings. A complete audit trial can be followed as the research design and method are described in details.

Ethical measures were taken with reference to the quality of research, obtaining of informed consent, participants' right to confidentiality, anonymity, privacy 
Table 1: Results of the perceptions of nurse educators with regard to the facilitation of reflective thinking of learners in clinical nursing education

\begin{tabular}{|c|c|c|c|c|c|}
\hline \multirow[t]{2}{*}{$\begin{array}{l}\text { MAIN } \\
\text { CATEGORY }\end{array}$} & \multirow[t]{2}{*}{ CATEGORIES } & \multirow[t]{2}{*}{$\begin{array}{l}\text { SUB- } \\
\text { CATEGORIES }\end{array}$} & \multicolumn{2}{|l|}{ THEMES } & \multirow[b]{2}{*}{$\begin{array}{l}\text { SUPPORTING } \\
\text { ATTITUDES }\end{array}$} \\
\hline & & & STRATEGIES & $\begin{array}{l}\text { ASSESSMENT/ } \\
\text { EVALUATION } \\
\text { METHODS }\end{array}$ & \\
\hline \multirow[t]{3}{*}{$\begin{array}{l}\text { Empowerment } \\
\text { of learners with } \\
\text { reflective } \\
\text { thinking skills }\end{array}$} & $\begin{array}{l}\text { Phase 1: } \\
\text { Awareness and } \\
\text { disequilibrium }\end{array}$ & $\begin{array}{l}\text { Knowledge and } \\
\text { receptivity } \\
\text { Comprehension } \\
\text { and response }\end{array}$ & $\begin{array}{ll}\text { - } & \text { Questioning } \\
\text { - } & \text { Lecture } \\
\text { - } & \text { demonstration } \\
\text { - } & \text { Narratives } \\
& \\
\text { - } & \text { Brain storming } \\
\text { - } & \text { Field trips } \\
\text { - } & \text { Simulations } \\
& \text { (Role play, } \\
& \text { gaming, videos }\end{array}$ & $\begin{array}{ll}\text { - } & \text { Direct } \\
\text { - } & \text { observation } \\
\text { - } & \text { Self-assessment } \\
\text { - } & \text { Poster } \\
\text { - } & \text { Woresentation } \\
\text { - } & \text { Observations of } \\
& \text { performance with } \\
\text { checklists and } \\
\text { rating scales. }\end{array}$ & $\begin{array}{ll}\text { - } & \text { Self-awareness } \\
\text { - } & \text { Open- } \\
\text { mindedness } \\
\text { - } & \text { Genuine } \\
\text { interest/enquiry } \\
\text { mind } \\
\text { - Willingness } \\
\text { - } \text { Motivation } \\
\text { - Enthusiasm }\end{array}$ \\
\hline & $\begin{array}{l}\text { Phase 2: } \\
\text { Interactive } \\
\text { constructing } \\
\text { process }\end{array}$ & $\begin{array}{l}\text { Analysis and } \\
\text { valuing } \\
\text { Synthesis and } \\
\text { organisation }\end{array}$ & $\begin{array}{ll}\text { - } & \text { Reflective } \\
& \text { journal writing } \\
\text { - } & \text { Nursing } \\
& \text { process/Case } \\
& \text { studies } \\
\text { - } & \text { Peer tutoring } \\
\text { - } & \text { Concept } \\
\text { mapping } \\
\text { - } \\
\text { - } \\
\text { - } \\
\text { Seminars } \\
\text { Workshops }\end{array}$ & 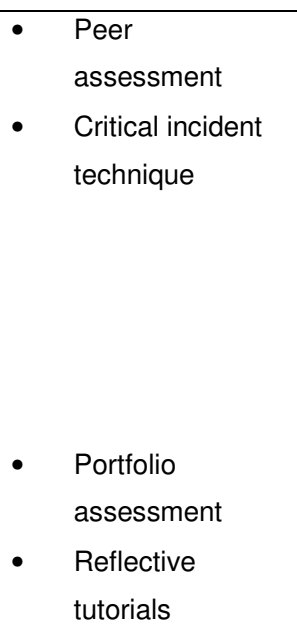 & $\begin{array}{ll}\text { - } & \text { Empathy } \\
\text { - } & \text { Trust and } \\
\text { - } & \text { Cospect } \\
\text { - } & \text { Courage } \\
\text { - } & \text { Perseverance } \\
\text { and flexibility } \\
\text { Consistency } \\
\text { and systematic }\end{array}$ \\
\hline & $\begin{array}{l}\text { Phase 3: } \\
\text { Consolidation for } \\
\text { rational decision- } \\
\text { making and } \\
\text { problem solving }\end{array}$ & $\begin{array}{l}\text { Evaluation and } \\
\text { Internalisation }\end{array}$ & $\begin{array}{ll}- & \text { Clinical } \\
\text { conference } \\
\text { - } & \text { Values } \\
& \text { clarification } \\
\text { - } & \text { Research / } \\
\text { community- } \\
\text { outreach } \\
\text { projects } \\
\text { Self-directed } \\
\text { learning } \\
\text { contracts }\end{array}$ & $\begin{array}{ll}- & \text { Research paper } \\
\text { presentation and } \\
\text { critiquing } \\
\text { - } & \text { Comprehensive } \\
\text { task } \\
\text { performance } \\
\text { assessment and } \\
\text { evaluation } \\
\text { Ward rounds and } \\
\text { unit } \\
\text { management } \\
\text { evaluation. }\end{array}$ & $\begin{array}{ll}- & \text { Justice } \\
\text { - } & \text { Responsibility } \\
\text { and } \\
\text { accountability } \\
\text { in decision- } \\
\text { making and } \\
\text { solving of } \\
\text { problems. }\end{array}$ \\
\hline
\end{tabular}


and termination of participation if necessary (Democratic Nursing Organisation of South Africa - DENOSA, 1998).

\section{RESULTS}

The description of the results will be made in accordance with Table One. First the main category (empowerment of learners with reflective thinking skills) will be described, followed by how this empowerment can be achieved through the phases of reflective thinking (categories) using the teaching strategies, assessment and evaluation methods guided by the supporting attitudes as perceived by participants in Chabeli (2001:116-147). The direct quotations of the participants are in "italics".

\section{EMPOWERMENT OF LEARNERS WITH REFLECTIVE THINKING SKILLS IN CLINICAL NURSING EDUCATION}

Empowerment is an enabling process of development and growth through which a person is enabled to take independent decisions and act autonomously with a view to making a contribution towards the development of their particular environment. This process is coupled with the development of applicable skills, attitudes and knowledge within a positive and democratic climate. These persons are therefore regarded as professionals in their own right as they are able to make a contribution to change through their particular power (Carl, 1995:7). The educational literature perceives empowerment within the facilitative role of the educator (Schon, 1991).

All the participants acknowledged the fact that the credibility of the profession can only be regained and maintained through empowerment of learners with reflective thinking skills in the clinical nursing education context. This is evidenced by a citation: "...teachers have a responsibility to empower their students with reflective thinking skills since education and thinking are inseparable, especially in the clinical nursing where things happen". Empowerment of learners with reflective thinking skills in clinical nursing education is the facilitator's most-needed challenging responsibility to improve practice. Paul (in Thomson \& Jolley, 1997:58, 59), as a member of the 'teaching for thinking movement', believes that without the ability to think and to reason, learners are intellectually, emotionally and morally incomplete. They lack the ability to make guided decisions drawn from a sound rational basis. Empowerment of learners with reflective thinking skills in clinical nursing education is described in accordance with the three phases of reflective thinking and their related subcategories and themes (Table One).

\section{PHASE ONE - AWARENESS AND DIS- EQUILIBRIUM}

According to Benner et al. (1999:568), awareness refers to the skill of "seeing" - a skill of recognition. Awareness is triggered by insufficient knowledge or the uncertainty in a given situation. Disequilibrium on the other hand refers to a disturbance in search for mental balance (Piaget in Woolfolk, 1990:46). The two terms are related in that insufficient knowledge or uncertainty will disturb the mental balance of an individual in a specific situation.

The participants were of the opinion that this phase is crucial to reflective thinking. They maintain that the purpose of this phase is to make the learners aware of their deficit in knowledge and feelings in a specific situation. The growing awareness of the self with regard to personal strengths and weaknesses in a particular situation will make the learners ask themselves reflective questions with regard to the situation. This assertion is evidenced by "... when you realise that the situation is strange or unique to you, you become uncomfortable and uneasy and this will make you ready to start the reflective process." Readiness, according to Thomson and Jolley (1997:129), is an attitude of mind that encompasses motivation and capability for the manifestation of self-directed learning behaviour. The awareness and disequilibrium phase is influenced by knowledge and the receptive attitude of the learner.

\section{Knowledge and receptivity}

Knowledge and receptivity as antecedents to the reflective thinking process are the lowest cognitive and affective thinking skills responsible for the formation of the self and basic domain specific knowledge necessary for the reflective thinking process to take place. Participants realised the important role played by knowledge acquisition in a specific situation as the building block on which reflective thinking is based. They indicated: "... the learner needs to have enough relevant 
knowledge in order to be able to link new experiences and make meaningful interpretations." Dewey (1933:99) asserts that no reflective thinking can occur in a vacuum. In each and every situation or discipline, basic knowledge plays an integral role in the understanding of the situation. As cited by Deits and Burden (1980:8), "We need to have at our finger-tips a great deal of background knowledge to better understand and interpret the situation".

Beyer (1988:49) urges learners to use credible sources and to seek as much information as possible related to the discipline as the key component of thinking. The question is how this acquisition of knowledge can be facilitated in clinical nursing education, especially in the first phase of reflective thinking. The following teaching strategies, assessment and evaluation methods and supporting attitudes were acknowledged by the participants and supported by literature: questioning, observation, lecture demonstration and narratives. Assessment and evaluation methods indicated at this level were as follows: self-assessment, interviews, and direct observation whilst supporting attitudes necessary were self-awareness, openmindedness and genuine interest/inquiry mind.

\section{Teaching strategies}

The participants agreed that questioning, observation, lecture demonstration and narratives are appropriate teaching strategies to facilitate basic knowledge acquisition in phase one. These will be described accordingly.

\section{Questioning}

The participants felt that one way of acquiring knowledge is through questioning in order to stimulate thinking, as cited: "...encourage students to ask thoughtprovoking questions, eh, higher level thinking questions that will force them to think". Participants also indicated: "...students must be eager to explore all avenues to get information". Beyer (1988:70) identifies the importance of appropriate questioning strategies in the development of reflective thinking. The focus must be on higher levels of thinking in accordance with Bloom's taxonomy (1956). Higher level questioning must be introduced gradually in this phase.

\section{Lecture demonstration}

The participants discussed the importance of lecture demonstrations in clinical nursing education at this level. They stated that lecture demonstration is an ideal teaching strategy to introduce basic clinical knowledge of the discipline as pointed out: "In clinical situation we use lecture demonstration to introduce a clinical theme somewhere in the ward. Basic knowledge is taught to students that way. Remember they are very junior, so we must take it slowly". Mellish, Brink and Paton (1998:113) refer to lecture demonstration as a lecture and a demonstration given simultaneously. The authors maintain that lecture demonstration needs careful planning as it involves a series of knowledge related to the procedure. A participant indicated: "That is why they must come with the knowledge such as anatomy, physics and chemistry in order to be able to integrate and use this knowledge in their clinical learning". Mellish et al. (1998:113) argue that this takes long because an explanation of the procedure and the reasons why it is carried out with special reference to the patient must be provided. This could be followed by a questions and answers session.

\section{Observation}

Observation is another way of acquiring basic clinical knowledge. One of the participants in this regard cited: "Encourage students to use experience as a source and field of reference to clinical learning. Take note of what is empirically observable, what they see, touch, smell or hear and be able to interpret the experience meaningfully. That is, encourage students to mobilise all sensory experience". Duminy and Söhnge (1986:200) concur with the participants in that observation or the use of audio-visual aids is the basis of the whole structure of the thinking process. Under observation is understood the perception of the external world through the medium of the senses. In building up from the observational level of thought to the more abstract levels, observation calls for the facilitator to use the necessary appropriate teaching and learning aids, such as models, pictures and films to establish a rich concrete layer of thoughts and feelings. These concrete impressions can be gained through experience of the real object in question.

Duminy and Söhnge argue that it would be a pedagogical 'sin' for the facilitator to talk about an object (syringe) at first-year level without making an attempt to implant the necessary visual perception. This places emphasis on the importance of placing learners in a 
variety of clinical situations, as cited by a participant: "Lack of experience creates a vacuum, expose students to different clinical learning situations under guided practice. Allow students to do simulations, demonstrations and field trips, that is, hands-on experience". This is why one tends to support fully the statement that teaching will remain 'idle talk' unless it is backed up by audio-visual aids (Duminy \& Söhnge, 1986:200).

\section{Narratives}

The participants were of the opinion that narratives written by learners at this level help the learner to reflect on clinical events, as indicated: "Storytelling makes the student to think back at what has happened, and this improves her thinking. Storytelling makes the student to be more relaxed. Students need to be in contact with these experiences and reflect on them". In support, Benner et al. (1999:564) are of the opinion that a storyteller should describe the clinical situation with a first-hand reporting style to include all the thoughts and feelings behind the clinical event. The learners are able to give a first-hand account of the critical incident that includes their concerns, hunches, dialogue, changed understanding over time and puzzles. The authors maintain that facilitators should encourage the learners to tell the story completely as is without fear in order to uncover the practical knowledge and their reading of the situation. The perceived assessment and evaluation methods suitable at this level are as follows: direct observation of performance, interviews and self-assessment.

\section{Assessment and evaluation methods}

Assessment and evaluation methods that were considered by participants as appropriate in phase one are as follows: direct observation, interviews and selfassessment.

\section{Direct observation}

According to the participants, direct observation of the learner's performance is an important assessment and evaluation method as one of them stated: “...you can actually identify the strengths and weaknesses of the learner there and then and make a follow up. Direct observation in the form of the learner demonstrating the procedure is an old method of assessment and evaluation, yet a good one". A demonstration is advocated by many authors as an effective evaluation method. Heidkergen (1946:305) treats demonstrations as one of the important generally used methods of clinical assessment and evaluation on the basis of exhibition and explanation. A demonstration activates several senses and correlates theory with practice. Learners are forced to think and re-think what they were taught and try to demonstrate it back in a meaningful manner. Clinical skills laboratory are helpful in this regard. A participant indicated: "Remember, at this level, students are not yet used to clinical practice, so they panic a lot. They need all the support from the teacher as much as possible. The environment must allow them to want to do, not to do because some authority wants her to do". Jarvis (1987:146) states that reflective thinking should not be authority driven, it should help liberate the minds of learners to think freely.

\section{Interviews}

The participants were of the opinion that interviews are not commonly used for assessing clinical competence, but did acknowledge the important role that the interviews played, as indicated: "It is actually a good method of evaluation, though it is not commonly used. It could be a variety to use interviews as an assessment method, but students get intimidated and their thinking gets blocked with this method". Benner et al. (1999:558) regard interviews as an excellent method of assessment since participants are given the chance to make themselves psychologically free, and a good rapport is established. The learner is encouraged to ask for clarification of the question during the interview. The facilitator is able to track the learner's clinical reasoning during the interview.

\section{Self-assessment}

The participants acknowledged the fact that learners should be exposed to the self-assessment method of evaluation at this level. They realised however, that learners need to be guided as indicated: "Selfassessment is good and needs to be introduced early in training, but they need to be assisted. They may be shy or frightened to talk about their performance. Relax the atmosphere. Self-assessment is a very important method of promote thinking because learners reflect back at their trail of thinking to arrive at conclusions. Therefore, teachers must encourage students to do self-assessment to ascertain who they are, what they stand for, what they are capable of doing". Gravett (1995:23) argues that involving students in the selfassessment of their own work should, however, not be 
undertaken without preparing the students. Gravett maintains that, for learners to accept this method, they first need to understand the rationale for implementing self-assessment.

\section{Supporting attitudes}

In response to the question of how the receptive attitude of learners can be facilitated to acquire clinical knowledge, all the participants were of the opinion that the learners' state of receptivity can have either a facilitative or obstructive influence on the acquisition of clinical knowledge. The participants felt that the facilitators must attend to this affective state, especially since most learners are still in their adolescent stage, what Jenkinson (1997:58) refers to as 'storm and stress, a traumatic and highly volatile stage. A participant stated: "Assist students to take stock of their feelings and emotions. Help them to clear off their negative feelings first in order to concentrate on positive feelings towards acquiring new knowledge. Understand the student's background, feelings and emotions and be there for them when they need your support and guidance".

Another participant further indicated: "Help them to be in control of their emotions and avoid disempowering emotions such as anger and frustration for these will only drag them down. Always encourage them to be positive and willing to engage in a situation". The facilitators have a challenging task in this regard. A participant said: "Help the students to develop their self-awareness, to be open-minded, to have genuine interest or inquiry mind, to change their attitudes and feelings towards the learning situation. Clearly describe the learning outcomes, the content, the methods and the evaluation process. Over and above, students want to know why they have to engage in learning certain clinical situations".

\section{Self-awareness}

With reference to self-awareness, participants acknowledged the fact that the point of departure in order to be receptive is to know yourself in relation to a particular situation. Self-awareness was considered very important in the initial phase of reflective thinking, as evidenced by a citation: "Self-awareness plays an integral part in reflective thinking. It is realised that when one becomes uncomfortable in a unique situation, one tends to doubt one's knowledge and will subsequently engage in self-questioning, such as: What does this mean? What is involved in this task? What do I know about this topic? What do I need to find out and what do I need to do to complete the task? So teachers must encourage students to do self-assessment to ascertain who they are, what they stand for, what they are capable of, gaps in knowledge and feelings, their strength and weaknesses".

Atkins and Murphy (1993:1190) postulate that selfawareness is the result of self-assessment sparked by an awareness of uncomfortable feelings and thoughts in a given situation when one realises that the knowledge is insufficient to deal with the situation. Lack of knowledge makes one to have no confidence and one can therefore be assertive, as supported by one of the participants who cited: "Assertiveness goes along with knowledge, so, encourage students to gain as much knowledge as they can and develop positive attitudes in the situation". Development of self-awareness needs one to be open-minded.

\section{Open-mindedness}

Beyer $(1988: 71,49)$ states in this regard that a key disposition, such as willingness to engage in reflective thinking, is a disposition to maintain until the goal has been achieved, and an insistence on evidence and reasoning to justify conclusions and assertions directly supports and drives the reflective thinking activity. Beyer urges facilitators to help the learners to persist in carrying out a thinking task and be open-minded about a situation. This assertion is supported by the participants who felt that the state of receptivity can be facilitated by open-mindedness and the belief in oneself, as stated: "Encourage students to be open-minded to the situation whether appealing or not. Students must learn to look back at previous experience in order to relate new knowledge openly. Uhm (thinking), open mindedness makes one to feel responsible and believe in oneself. Yes, belief is an internal truth and openmindedness is actually a virtue to the facilitation of reflective thinking".

\section{Genuine interest/inquiring mind}

It was argued that without genuine interest or an inquiring mind, no reflective thinking could take place. A participant indicated: "Without genuine interest, it is like a student looking at you but in the heart she/he in enjoying himself at the gig". Genuine interest demonstrates motivation in what one is doing. Dewey 
(1933:30) refers to genuine interest as 'wholeheartedness', where the learner will have an active desire to listen to more sides of the story than one. One will have genuine interest to analyse the feelings and emotions of the whole experience. Positive receptivity plays an important role in the comprehension of learners in order to respond appropriately in a given situation.

\section{Comprehension and responding}

Participants acknowledged the fact that comprehension plays an integral part in reflective thinking. Dewey (1933:133) argues that without comprehension no reflective activity would take place. Instead, ideas, meanings and facts would heap up like grains of sand. Teachers are faced with the challenge of selecting learner-centred and learner-friendly teaching strategies that will facilitate comprehension of learners.

\section{Teaching strategies}

Participants felt that comprehension is brought about by the ability to reason, which can be developed through strategies such as brainstorming, field trips and simulations by role-play, gaming and videos.

\section{Brainstorming}

Participants acknowledged the fact that brainstorming is one teaching strategy that can facilitate the reasoning ability of the learner, as stated: "It is through reasoning that one is able to comprehend issues. A student who can reason logically can save lives because she has good listening skills, gives herself time to reflect back to previous experience in order to make meaningful interpretations". A participant indicated: "Reasoning ability is a pillar to facilitate reflective thinking which teachers must focus on". Learners' reasoning skills have to be facilitated from the beginning and increased with their intellectual development. The facilitators should make explicit the steps they take to order statements logically within an argument and describe how conclusions are reached, and thus demonstrate the value of such deliberative activities to the learners when handling verbal information and written data.

It also came out clear that the success of brainstorming is brought about by linguistic clarity, cultural sensitivity and accommodation, which play an important role in facilitating comprehension. This assertion is evidenced by a citation: "Language enables one to think because you can add meaning through different interpretations of different situations. Language helps one to reason and to take part meaningfully in an argument or any form of discourse since you can express yourself freely. You can actually put ideas together to clarify a point". In support, Duminy and Söhnge (1986:35) state that thought requires language for its expression, and language is derived from culture. In the execution of a thinking task, one cannot always stay in the domain of the observational aspect, the vehicle for entering a realm of abstraction is language. In this regard, Van der Stoep and Louw (1984:80) state that mastering a language enables one to address reality communicatively and as such, the appeal of language forms the basis of one's thinking.

Participants believed that culture could either be an obstacle or facilitate the thinking process of learners at all levels of training as cited: "It is in the culture of some students that you may not invade their space. Coming closer makes them feel uncomfortable and this distracts their attention and thinking. To some students, it is against their culture to look directly into the eyes of a senior person because it is a sign of disrespect. The interaction between students, and that between the student and the teacher will be greatly hampered in such instances unless the teacher becomes sensitive to such cultures. Knowing the students' background is a necessary requirement for teachers".

They further stated: "Yet, different groups react differently to group interaction. They may not respect or tolerate one another readily. One may have the liking to help others, the other may be a loner and believe in own effort. Again, you may be surprised why one group performs better than the other groups. So, get to know their backgrounds and mix the groups to encourage tolerance and group interaction".

All the participants agreed that it is imperative that facilitators should be culture-sensitive in order to facilitate reflective thinking. One of the assumptions stated by proponents of multicultural education in Biehler and Snowman (1997:252) is that cultural values and experiences predispose learners to thinking and behaving in particular ways. When these values and experiences are understood and accepted as worthwhile, incorporated into instructional lessons, and 
rewarded by the facilitators, the learners involved will perform better academically than they would otherwise. However, the authors assert that facilitators must be culture sensitive and acknowledge cultural differences in learners. One participant stated: "Expose learners to different clinical learning situations where they will be able to brainstorm clinical issues under guidance, that is, a hands-on experience". Quinn (1988:176) believes that brainstorming is a way of obtaining creative solutions to a problem because each member can generate as many ideas as possible, especially where criticism is discouraged.

\section{Field trips}

This strategy was welcomed by participants who indicated: "Field trips are a pleasure to use if you have planned them well. Students get the first-hand experience and are able to correlate theory to practice. They are a pain if not well-planned for you will be refused entry to start with - which is quite embarrassing at times". According to Heidgerken (1946:379) field trips are an educational procedure by which the learner studies first-hand objects and materials in their natural environment. The learner comes into direct contact with the world of nursing. The author warns that without proper planning, field trips will serve no purpose. The same warning applies to simulations in the form of role-plays, gaming and videos.

\section{Simulations (role-play, games, videos)}

According to the participants, simulations are a common teaching strategy to teach clinical knowledge as indicated: "Nursing deals with the lives of patients and we cannot risk their lives by allowing students to learn procedures first time on them. You can imagine a student learning suturing for the first time directly on the patient, that would be inhuman". Heidgerken $(1946: 385,386)$ gives a warning with regard to simulations that mere observation does not promote learning, but to see and feel an object is lifelike and better than reading about it, or just hearing it being described. Quinn (1988:179) asserts that lifethreatening procedures, such as cardiac arrest, should be simulated in the form of a role-play or shown on the video. The learners should have enough practice before they can perform the procedure. The learner should have had an opportunity to internalise the sequence of the procedure and the rationale to perform some actions through practice. These strategies need to be assessed and evaluated for their effectiveness.

\section{Assessment and evaluation methods}

The participants believed that, among others, the appropriate assessment and evaluation methods that could facilitate comprehension of learners could be poster presentations, workbooks and observations of performance using checklists and rating scales.

\section{Poster presentations}

Participants agreed that poster presentations are not commonly used in clinical nursing education yet, they acknowledged their importance as one of them cited: "This is one method that is not common in nursing education, but it can stimulate the student's thinking". Mellish et al. (1998:195) are of the opinion that the potential for learning, which is presented when the students construct posters and have to negotiate the criteria for evaluation, is unlimited, especially if they do it in groups. It facilitates the sharing of ideas and feelings to make a meaningful construction.

\section{Workbooks}

With regard to workbooks, participants regarded a workbook completion as the traditional method of assessing clinical competence. They noted that if a workbook is used properly, it could become purposeful. Its worth becomes defeated by dishonesty of the assessor and the learner, as stated: "Workbooks that are just signed for the sake of signing to get the student out of your way serve no purpose. Tutors must be honest for the benefit of the learners". Mellish et al. (1998:123) urge that workbooks should be designed carefully and explained to the learners. These books should be simple, and the learners should be quizzed about the data recorded and the underlying scientific principles in order to promote their thinking. The authors maintain that complete honesty is necessary for the success of this strategy.

\section{Observation of performance by using checklists and rating scales}

The participants felt that direct observation remains the hallmark of clinical assessment and evaluation. They indicated the importance of OSCE (objective structured clinical examination) in the clinical evaluation of learners, as indicated: "OSCE can benefit the learner if well planned to test higher order thinking comprehensively, and can produce robot-like nurses if the purpose is not 
clearly defined to assess the ability of the students to think'. Mellish et al. (1998:252) assert that OSCE can be very stressful for the learners and the facilitators if not well planned. However, it remains a popular means of evaluating clinical competence. Evaluation must look at the comprehensive performance of the learner, that is, the cognitive, affective and the psychomotor skills (Major \& Pines, 1999:122).

\section{Supporting attitudes}

Supporting attitudes such as willingness, motivation and enthusiasm were perceived as playing an integral part in facilitating the comprehension of the learners in clinical nursing education.

\section{Willingness}

Participants made it clear that these affective components apply in all phases, depending on the involvement of the strategy and on the individual as well as the facilitator. They believed that the learner would demonstrate comprehension of knowledge by responding positively to the learning situation. They would demonstrate willingness, motivation and enthusiasm to participate actively in their learning, as quoted: "Once the student has understood the learning experience, she wants to satisfy her curiosity by developing the willingness and interest in applying the experience. She wants to try out this and that. She becomes motivated to explore the situation. She willingly becomes open to all situations. She will be initiative, enthusiastic and assertive eh...(thinking). By the way, assertiveness goes together with knowledge. It is therefore necessary to determine what the student already knows".

According to the participants, no learning will take place without the willingness to learn. One indicated: "Help the learners to develop the desire and willingness to change their attitude and feelings toward the learning situation. Clearly describe the learning outcomes, the content, the methods, and the evaluation process. Over and above, students want to know why they have to engage in learning certain clinical situations". This notion is supported by Knowles (1980:44) in stating that learners are adult learners and their receptivity to learning depends on what they feel they need to know and apply the new knowledge and skills right away.
Participants stated that motivation is actually an important didactic principle of teaching and learning as cited: "When students appreciate their importance in taking active part in learning, then you must know that intrinsic motivation has taken place". Heidgerken (1946:95) asserts that teaching is activating the learners to accept responsibility for learning, instilling within them their proper motives. Heidgerken maintains that the facilitators must be aware that the learners come to the profession with fully established and different motives, some of which are good, and others which must be modified with the facilitator's guidance. The author urges that the facilitators establish the background knowledge of the learner prior to introducing new themes. Motivation, especially intrinsic motivation, goes hand in hand with enthusiasm.

\section{Enthusiasm}

Enthusiasm is regarded as the driving force for learning. A participant stated in this regard: "A good teacher is one who has enthusiasm, not only for his subject but for life itself. He conveys this enthusiasm and vitality to his students in every word he speaks". Pauw (1993:26) regards enthusiasm as the art of combining subject knowledge with humanness. Enthusiastic facilitators will convey the same enthusiasm to the learners and make their teaching lively and interesting. This motivates the learners to want to be like the facilitator and thus take responsibility for their own learning, to be self-directed, self-monitoring and selfregulating (Knowles, 1980:44). The positive and motivated response of the teacher will encourage the learner to be involved in the critical analysis of whatever clinical situation in order to make a meaningful interpretation and construct knowledge through interactive facilitation. This leads the discussion to the second category, which is the second phase of the reflective thinking process - the interactive constructing process.

\section{PHASE TWO: INTERACTIVE CON- STRUCTING PROCESS}

Pietrofesa, Hoffman, Splete and Pinto $(1978: 4,6)$ define the word interactive as "a mutual relationship of individuals seeking help..., always facilitative and fostering growth..., it is a mutual enterprise and is based on respect for the individual..., specific skills such as empathy, attending, listening, responding and self-

\section{Motivation}


awareness are used". The constructing process refers to a course of action towards building or forming by interpretation or explanation (Concise Oxford Dictionary, 1995). The interactive constructing process phase is characterised by active participation of learners in constructing their own knowledge, skills and values through interaction. It is influenced by the higher order cognitive and affective thinking skills such as analysis, valuing, synthesis and organisation. The teaching strategies, assessment and evaluation methods as well as the supporting attitudes that were perceived to be appropriate in facilitating reflective thinking of learners in clinical nursing education will be described.

\section{Analysis and valuing}

In response to the question 'How can the interactive constructing process of reflective thinking be facilitated through the use of analytical thinking skills supported by relevant values in clinical nursing education?' the participants indicated that analytical thinking skills play an integral part in the constructing process of reflective thinking. According to one of them this is so because: "Analysis is where elements are broken down into its component parts for the purpose of better understanding and interpretation. I mean the ability to break information in order to identify, describe, classify, compare and contrast issues and to construct better meaning out of the situation. It is quite involving; learners must actively take part in their learning. Teachers must provide strategies that will facilitate interaction, and cooperation, that is...uhm.. (thinking), working together, arguing and sharing information to better understand the situation".

Beyer (1988:165) postulates that analysis is an integral part of both synthesis and evaluation. Analysis is used at numerous points in the different thinking strategies in trying to identify a problem, in clarifying a problem, in generating hypotheses or potential solutions, and in testing the efficacy of these solutions. Beyer argues that analysis is the most widely used of all microthinking skills, and in analysing, individuals seek to examine and explore the situation in detail to establish meaning.

This is evidenced by one of the participants who cited: "Once the student is eager to know something in a situation she respond by applying critical analyses and examine the situation by breaking the information down into separate components and critically reflect on the relationship among its constituent parts. As the student analyses the situation, s/he engages in logical reasoning and justify her reasoning by arguing her point out". Probing the question further, the participants were asked to indicate the teaching strategies and evaluation methods that would facilitate analytical thinking skills, and they indicated: "It is difficult to pinpoint a strategy because a strategy depends on the creativity of the teacher, but reflective journal writing, nursing process or case studies, peer group teaching and concept mapping would be appropriate. Peer assessment and critical incident technique would help to assess students comprehensively at this level'.

\section{Teaching strategies}

The teaching strategies in phase two demands much interaction in the form of discussion, discourse and debate to enable learners to meaningfully construct clinical knowledge, skills and values. Participants identified the following teaching strategies as being appropriate: reflective journal writing, use of the nursing process/case studies, peer group teaching and concept mapping.

\section{Reflective journal writing}

With regard to learners writing down their thoughts, participants were of the opinion that the ability of the learners to demonstrate their thinking process facilitates reflective thinking. The learner is able to link the experience with the previous knowledge while performing the action. They believe the use of reflective teaching methods is a step in the right direction, as cited: "Reflective teaching methods engage the students in active thinking since she can reflect on the experience as it happens or after, and make relevant adjustments as a result. This ability is demonstrated when a student is writing a reflective journal or compiling a portfolio, where they engage in interactive dialogue and discourse, debates and narratives". One of the participants further indicated: "Expose students to more thought-provoking situations that demand interaction to be able to construct their knowledge and skills with guidance".

Shields (1995:455), in encouraging the use of reflective journal writing, states the following: "journal writing should be less descriptive and more reflective. Grow 
easy with the idea. Get more out of it. You don't have to write about all the observations you did or saw, but what is of significance to nursing at that time. Read and reflect on what you have written and say, 'Well, I'll handle it differently next time'. Go and read up about it and get other people's opinions about it. Think... I would work out how it would be best to handle the situation again". Shields asserts that learners would show signs of developing skills of self-analysis and 'critical knowing'.

\section{Nursing process and case studies}

A participant indicated, "Literature has described the value of nursing process in facilitating reflective thinking. Nursing process challenges the learner to think critically. This can be achieved by encouraging learners to engage in arguments and to justify their opinions". In this regard, Atkins and Murphy (1993:1190) state that critical analysis involves examining the components of a situation, identifying existing knowledge, challenging assumptions, imagining and exploring alternatives. A critical analysis of knowledge is undertaken, which involves examining how relevant knowledge is to an individual situation.

However, the objective of this study is not to describe what analysis can do but how analytical thinking skills can be facilitated through the interactive constructing process of reflective thinking. In this regard a participant stated: "Assist students to genuinely assess the patient, listen carefully to what is said, break down information and critically reflect on their relationship by encouraging interactive dialogue, debate and discourse...eh (thinking) sharing of ideas, thoughts and feelings. You can ask if there is any relationship in what the patient says or feels with what the learner knows, and what is the nature of that relationship". The participants further indicated: "Reflecting on your own can also be beneficial in that the student has time to introspect, retrospect, ponder and meditate thoughtfully at the experiences, but it can sometimes lead you to limited understanding which can be clarified through interactive group activity".

Case studies as a teaching strategy in clinical nursing education was regarded as one of the traditional methods. Participants, however, acknowledged the important role it plays in clinical nursing education, as indicated: "Case studies can be a waste of time if carried out like robots following the format of writing a case study from the book. We use case studies a lot for teaching because students learn by exploring and experimenting on her own, and in consultation with the sisters in the ward'. Quinn (1988:183) confirms the assertion by stating that case studies can be used to very good effect in bringing theoretical issues closer to the real world of nursing. They can evaluate the care of a patient in the light of their own knowledge and skills. They can integrate information from a wide range of perspectives and experience.

\section{Peer tutoring}

Participants acknowledged the fact that peer tutoring is not commonly used in nursing. However, they noted the fact that it is a good strategy to use, as quoted: "Peer group teaching is good but is not commonly used. Students become free in expressing their mind and how they feel, but it can become nasty if students use it to get back at their colleagues by asking nasty and provoking questions". Gravett (1996:17) asserts that peer group interaction can be used to explore and clarify ideas, to solve problems, to generate hypothesis, to discuss questions and much more. It gives learners the opportunity to reflect on their learning as they share and negotiate knowledge in a community of learners.

\section{Concept mapping}

Concept mapping was regarded by the participants as one teaching strategy that facilitates learners to think, as stated: "It works out better if you group learners together to map out the concepts of a specific theme or experience. They would argue and debate until they get a meaningful map right'. The teacher will have to explain the purpose and the learners' expectations as to how the exercise has to be performed. Quinn (1988:293) argues that the mapping analysis of the concept or theme is important as it draws out the learners' existing knowledge and stimulates their thinking skills.

\section{Assessment and evaluation methods}

Like the teaching strategies described, the assessment and evaluation methods for this phase require varied and authentic methods that are learner-centred. The following methods were suggested by participants: peer group assessment and critical incident technique methods.

\section{Peer group assessment}

Participants felt that peer group assessment like peer 
group teaching, is not commonly used. Yet, it is good to encourage a climate of freedom, respect and trust. One participant indicated: "When students evaluate themselves, they do it more authentically and much more relaxed. We should make use of this method frequently. I remember during our days when we used to do proficiency classes to demonstrate a procedure to our fellow students, one would be responsible for the acquisition of knowledge by arranging practices during your off-duty time, get help from everybody in the ward, arrange for the presentation with the help of the charge sister. You really felt in control of your learning". Gravett (1995:24) agrees with the notion by saying that peer assessment needs a great deal of preparation, and it strengthens the learner's skill of selfassessment. Gravett maintains that a useful way of developing skills of self- and peer assessment is to involve learners in providing feedback, rather than formally assessing each other's work.

\section{Critical incident technique}

"Strategies such as critical incident technique can facilitate reflective thinking because learners write down exactly what she did in her own understanding, having assessed the worth or significance of the action. Justification of the worth is necessary. However, the learner has to be honest with herself and identify exactly what is critical, or else it will be a useless exercise", stated one participant. Ewan and White (1984:210) maintain that the critical incident technique can be used to develop a performance record based on core behaviours, and it fits well with the criterion-referenced assessment where the core behaviors for mastery have been identified. Unfortunately, there are logistic problems arising from uneven enthusiasm, and difficulty in establishing consensus on categories into which incidents fit. Dachelet, Wemett, Garling, Craig-Kuhn, Kent and Kitzman (in Ewan \& White, 1984:210) assert that critical incidents can be used to obtain a holistic perspective, a broad picture of activities in a clinical practical setting - they provide details of the categories and criteria used to classify incidents.

\section{Supporting attitudes}

With reference to the supporting attitudes to facilitate analytical thinking skills, participants mentioned, among others, empathy, mutual trust and respect, confidence and courage.

\section{Empathy}

Empathy was considered as the driving force of reflective thinking, as stated: "The bottom line of reflective thinking is empathy, since group dynamics depend on the empathetic understanding of other students' opinions and feelings". Empathy plays an important role in facilitating interaction since it is manifested in feelings, thoughts or the behaviour of others (Bennett, 1995:138). This author asserts that empathy enhances the understanding of the different cultural values and beliefs of others, while Thomson and Jolley (1997:69) maintain that empathy involves mutual respect and trust, good listening skills and patience, good interpersonal skills and communication skills.

\section{Trust and respect}

These values were also recognised as important in facilitating reflective thinking by the participants, as indicated: "Teachers and students must be flexible and accommodate diverse value systems to promote mutual trust and respect in order to enhance understanding of one another". In this regard, Van Hoozer, Bratton, Ostmoe, Weinholtz, Craft, Gjerde and Albanese (1987:188) argue that successful interactive discussion depends on the teacher creating a good rapport with learners, creating a climate of mutual trust and respect, showing sensitivity to learner's response and stimulating active participation.

\section{Confidence and courage}

A participant stated: "Students who lack confidence and courage cannot be fruitful in the discussion where arguments are necessary, that is for sure. They sit there like frightened people in need of protection". Indeed, courage and confidence give learners 'the will to learn', confidence in their own ability to achieve, and it determines the intensity, persistency, kind and amount of effort which the learners put forth to accomplish a task (Heidgerken, 1946:88). Heidgerken asserts that courage and confidence in one's own ability means that an individual will initiate new methods of action, sustain long periods of deep thought, and continue trying even after several failures. Having described how analysis and supporting values could be facilitated, it becomes important to describe how synthesis and organisation thinking skills can be facilitated.

\section{Synthesis and organisation}


At this level, learners are expected to have developed intellectually. Hence, the participants acknowledged the need for cooperative interaction, as stated: "Encourage group work such as seminars and workshops. Students must be involved and kept busy purposefully in order to encourage cooperative learning and develop higher order thinking skills". Participants acknowledged the fact that synthesis is more complex since it involves putting the separate components back in relation to previous knowledge so as to establish meaning. They believed that it is only when you have synthesised, wellorganised information that you can perceive the situation differently and develop new insight and perspective, as cited: "One way to facilitate synthesis is to encourage students to formulate hypothesis from the experiential world. From the knowledge gained, they can make relationships between phenomenon creatively by using their imagination. They can even make inferences to stretch their thinking further".

This belief is consistent with Beyer's (1988:350) definition of synthesis that it involves combining separate elements to produce a coherent whole, pulling together, unifying and creating. It also involves one inventing a creative hypothesis out of an in-depth analysis of a problem, form generalisations, concepts, plan of actions and theories. Beyer $(1988: 65,297)$ states that one may develop an original solution, invent an argument by combining reasoning and evidence in a new way, or invent alternatives or reason from old truths to a new truth.

\section{Teaching strategies}

The teaching strategies stated above will be discussed simultaneously as they share common characteristics.

\section{Group projects, seminars and workshops}

Synthesis needs one to be highly creative and imaginative so as to be able to generate, invent, compose and design new insight and perspectives, as evidenced by: "You, the teacher, must be highly creative, be outgoing, witty, open-minded and imaginative. Use metaphors, analogies, picture representations to facilitate meaningful interpretation and understanding during workshops and seminars in order to view situations differently. To be imaginative, they must use their intellectual and imaginative thinking to be able to see relationships in what they have learnt and reflect to the previous experience in a broader perspective. This will be achieved by prompting thought-provoking questions to members of the group". On the other hand, Beyer (1988:297) states that creativity involves the application of knowledge, imagination and judgement to problem solving. It is guided and driven by a desire to seek the original. It values mobility, it revels in exploration, it feeds on flexibility and it honours diversity; Chabeli (1999:71-72) reiterates this assertion.

\section{Assessment and evaluation methods}

When participants were asked about the assessment and evaluation methods that will facilitate synthesis and organisation thinking skills at this level, they indicated that, among others, portfolio assessment and reflective tutorials could be appropriate.

\section{Portfolio assessment}

Participants acknowledged the fact that portfolio assessment is a new strategy that emerged with the outcomes-based education and therefore it is not yet popular in clinical nursing education. Those who were familiar with the method gained the knowledge from the theoretical aspect, as indicated: "Based on the theoretical point of view, portfolio assessment seems to be good in stimulating thinking. We shall have to get more knowledge about portfolios and put them into practice". That was a genuine perception on the part of the participants. From literature, portfolio assessments are regarded as highly effective in facilitating reflective thinking. Van der Horst and McDonald (1997:194) state that portfolios provide evidence of a learner's knowledge, skills, attitudes and academic development that afford the facilitator opportunities for continuous assessment and summative evaluation. It also offers a concrete way for learners to evaluate their own work from new perspectives. The authors maintain that learners will learn to work cooperatively, learn how to approach problems, learn how to plan, research, develop documents and evaluate themselves. Learners develop self-monitoring and self-regulating skills with discipline.

\section{Reflective tutorials}

Like portfolio assessment, participants acknowledged their worth, but indicated that they are not commonly used as indicated by a citation: "Reflective tutorials are good but not common since situations are probed with other learners". Glen, Clark and Nicol (1995:66) state that the purpose of reflective tutorials seems to 
be to convert a work experience with some learning into a learning experience about work by probing each clinical situation in order to pick out the learning that has occurred. Glen, Clark and Nicol (1995:67) maintain that reflective tutorials are reflective sessions conducted by learners where learners probe issues at a deep level with the teacher who will keep on probing with thoughtprovoking questions until mastery of the performance task is determined. Quinn (1988:164) points out that the purpose of reflective tutorials will largely determine its implementation whereas Mellish et al. (1998:127) are of the opinion that tutorials are suitable for senior students who are able to identify their learning gaps. Learners are given topics to prepare and present to the group with the aim of diagnosing their weakness and getting them to be involved as much as possible in their work. This strategy needs to be researched further to determine the extent of its worth.

\section{Supporting attitudes}

The supporting dispositions to facilitate synthesis thinking skills were also identified by participants as perseverance, flexibility, being systematic and consistent to organise information creatively into meaningful themes and patterns.

\section{Perseverance and flexibility}

Perseverance, flexibility, consistency and systematic patterns when organising information were regarded by participants as important components as indicated: "You need to encourage learners to persevere, have patience, be flexible and systematic when creating new patterns and themes. Remember most learners are still in their late stage of adolescence and therefore lack patience". Ennis (in Thomson \& Jolley, 1997:64) found that learners would need to be open-mined, willing, flexible and patient in order to view points and other alternatives in an orderly manner, taking into account the total situation.

\section{Systematic aspect and consistency}

For learners to develop skills to organise information, participants felt that they need to be creative, highly imaginative and make use of the existing frameworks, such as the nursing process, as stated: "Create situations that will need a student to organise information in a systematic and logical manner. The student must create systematic patterns that are consistent, from gathered information such as nursing diagnosis to make meaningful interpretation and to enable her to design a plan. Maslow's hierarchy of needs analysis can also help students to organise information meaningfully". Biehler and Snowman (1997:59, 112) contends that organisation systematises or combines the thinking processes into coherent, logically interrelated systems that are consistent. The learner is able to compare and contrast meanings, themes, characters, settings and reasons. This organisation capacity makes those thinking processes efficient and powerful, and allows for a better 'fit' or adaptation of the individual to the environment.

\section{PHASE THREE: CONSOLIDATION FOR RATIONAL DECISION-MAKING AND PROBLEM-SOLVING}

Consolidation refers to the process of combining for the purpose of making a strong whole (Little Oxford Dictionary, 1986). Gravett (1996:13) contends that during the consolidation phase the connection between concepts and principles should be focused sharply. The consolidation phase is the most complex phase that requires learners to consolidate all the knowledge, skills and attitudes gained through extensive meaningful clinical experience. It is the phase where Benner (1982:405) refers to the learner as being proficient in clinical competency. It is influenced by the highest cognitive and affective thinking skills, such as evaluation and internalisation.

\section{Evaluation and internalisation}

When participants were asked how the consolidation phase of reflective thinking can be facilitated using evaluative and internalisation thinking skills in clinical nursing education, they were of the opinion that comprehensive consolidation of clinical knowledge, skills, attitudes and values would enable learners to make rational clinical decisions and solve problems. Participants pointed out that this ability can be acquired through the use of complex teaching strategies that foster collaborative group interaction, as indicated: "Learners should be engaged and involved actively with clinical conference, values clarification sessions, research-based projects and self-directed learning contracts. Students at this stage must be highly involved in making decisions and solving problems proficiently and independently in clinical settings". 
According to Benner (1982:405), a proficient learner is expected to perceive situations as 'wholes' rather than in terms of aspects. At the proficient level, learners should be taught by using strategies in which their ability to grasp the situation is solicited and taxed. The indicated strategies will be described.

\section{Teaching strategies}

The teaching strategies stipulated above require extensive interaction between learners and the environment where learners make use of the knowledge, skills and values acquired throughout the entire training. Ausubel (1968:57) refers to this as a valuable and meaningful 'cognitive structure' on which learners could link future experiences when making clinical decisions and solving problems.

\section{Clinical conference}

Participants were of the opinion that senior learners should be involved in a clinical conference, as quoted: "Students will get a chance of holding debates and discourse about the condition and progress of patients with other members of health care providers such as radiographers, physiotherapists, dieticians and medical students. It is a method of self-check as they share information with others. Such multi-disciplinary debates help students to stimulate their thinking as they interpret, reason and justify their opinions and accommodate each other. Professional growth takes place". Heidgerken (1946:356), in describing the value of clinical conference, states that clinical conference requires an attitude of critical inquiry, wide interest, and an appreciation of social values, opportunities and responsibility. Heidgerken further argues that given the opportunity to solve active problems in real-life situations independently, can develop the learner's attitude of intellectual honesty, courage, self-confidence and openmindedness in attacking and resolving problems.

\section{Clarification of values}

Participants acknowledged the worth of using clarification of values as a teaching strategy. Yet, it is not commonly used. A participant stated: "This is one strategy that can shape the students in making ethical and moral decisions and solve problems in that regard only if we can use it more often". Indeed, value clarification at this level is ideal in teaching learners how to clarify their values and those of others, but it has been used relatively recently in nursing education
(Mellish et al. 1998:177). The authors maintain that it is a strategy especially recommended for teaching ethics and decision-making since one is made consciously aware of the values and underlying motivations that guide one's actions and provides opportunities for learners to clarify and defend their values through the 'valuing process'.

\section{Research/community based projects}

"Senior nurses need to be involved in research and community-based projects, and present the findings on a research day scheduled for the purpose", stated one participant. The participant expressed this perception with enthusiasm to emphasise the importance of this strategy. Heidgerken (1946:350, 351) is of the opinion that the value of research projects far outweighs the disadvantages because research projects give the learner freedom of thought and action, and provides for whole-hearted purposeful activity that is learner-centered. The author maintains that group research projects develop a spirit of cooperation and community interest.

\section{Self-directed learning contracts}

Participants aptly regarded learning contracts as a strategy suitable for senior learners, as indicated: "Learning contracts can be used for final-year students because they have grown in the profession and can take responsibility and ownership for their independent learning and clinical judgement. Unfortunately, learning contracts are not commonly used in nursing education". To reiterate this assertion McAllister (1996:201) believes that learning contracts is a strategy that is underutilised by institutions of higher education. According to Biggs and Moore (in McAllister, 1996:201), nurses, like other professionals, need to be self-reflective, self-aware, be able to assess their own work and judge the extent to which objectives have been met. The authors maintain that contract learning would make this possible and promote deeper and more achieving level learning. Learners are able to identify where their knowledge deficits are. They have a sense of control, encourage creativity and feel independent and autonomous in making decisions.

\section{Assessment and evaluation methods}

With regard to the assessment and evaluation methods at the third phase of reflective thinking, the participants agreed that the strategies that would be appropriate 
should be comprehensive in nature. A participant indicated: "It is not easy to evaluate finalists on their clinical competence. A comprehensive approach would be the line of direction such as research paper presentation and critiquing, ward round unit management evaluation and the comprehensive performance task assessment and evaluation and many others depending on the creativity of the teacher. It must be a joint effort anyway".

\section{Research paper presentation and critiquing}

This method of evaluation was appreciated by all participants because they strongly felt that it contributes to the growth of the learner. One of them indicated: "Students will grow in their thinking and research abilities. They will demonstrate their knowledge of research to the authorities by presenting the findings in public. In this way, the care of patients and the conditions of the service will be improved'. Quinn (1988:407) points out that, projects, taken in the form of a small research study in which some aspects of nursing care are examined play an integral part in clinical nursing education. Quinn urges facilitators to ensure that all the correct procedures have been followed with regard to the health authority ethics committee, and findings should be communicated to the relevant authorities in the presence of the research experts.

\section{Comprehensive task performance assessment and evaluation}

This type of evaluation was regarded as ideal by the participants who felt that: "Procedures still need to be assessed and evaluated at this level, but with finalists, it must be more comprehensive and more inclusive to integrate all the four nursing disciplines. It therefore needs to be jointly planned". The notion is in keeping with the view of Major and Pines (1999:122) that interaction, collaboration and information sharing play an integral part in decision-making as those decisions have an influence on the way things get done. They maintain that collaboration drives change, allows teachers to engage, reflects on and collaboratively agrees with solutions to problems. A comprehensive OSCE as a method of clinical evaluation could be planned jointly by the facilitators and other stakeholders, including the community (Chabeli, 2001:86-87).

\section{Ward-round and unit management evaluation}

The participants felt that this is an old and very effective method of evaluating the learner's ability to manage the ward in a comprehensive manner, as stated: "This is examining whether students are ready to be efficient sisters of tomorrow. How they can maintain quality through their observational and managerial skills". Quinn (1988:406) maintains that learners must maintain the highest standards of care and management even in the face of 'we do not do it like that in this ward'. Learners will integrate the theoretical knowledge with holistic practice through comprehensive assessment and evaluation. If evaluation has been done successfully, the learners will internalise and adapt to the new professional value system that will improve the decisionmaking and problem solving ability in a situation.

\section{Supporting attitudes}

The participants were of the opinion that learners need to be fair in their judgement and take responsibility and accountability for their decisions in practice. Justice, responsibility and accountability become appropriate in supporting reflective thinking in this phase.

\section{Justice}

When asked how they can facilitate reflective thinking using the internalised and consolidated knowledge and experience gained for making rational decisions and solving problems in clinical nursing education, participants stated that internalisation is actually the highest affective thinking skill where learners should actually demonstrate their ability to reflect on issues or clinical situations fairly as cited: "It is therefore necessary that the learners must be fair and take responsibility and accountability for the decisions they make". Participants regarded justice as an important aspect of decision-making and solving of problems in clinical nursing education. A participant indicated: "Justice is the hallmark in all integrated approaches where decision making and problem solving has to be made". Heidgerken (1946:116) argues that justice does not mean harshness. It means fairness, the quality that must ever penetrate all the teaching and assessment activities. Heidgerken maintains that partiality and favouritism must be excluded from teaching at all times as it blocks the ability to facilitate reflective thinking.

Once the learners have evaluated and internalised professional values, what is right and what is wrong, they are ready to practise independently and autonomously, taking full responsibility with 
accountability in their decisions. They can now make informed clinical decisions and solve problems.

\section{Responsibility and accountability}

With regard to encouraging learners to be responsible and accountable for the decisions they take independently, a participant stated: "Allocate senior students to be in-charge of the wards to allow them to exercise their ability to take responsible decisions they can account for based on evidence. They will be in a position to make their own interpretations of events, take risks, exercise their independent thoughts and feelings as they take informed decisions, make clinical judgements and solve problems on their own".

Nursing is generally known to be characterised by a multicultural, pluralistic society, such as in South Africa. These societies need virtues that will foster learners to be independent practitioners who should make clinical, ethical and moral decisions, and accept responsibility with accountability for their actions, which is actually an outcome of the reflective thinking process. They need to practise independently and autonomously. Botes (1995:23) postulates that the fundamental characteristic of an independent, autonomous practitioner is the ability to reflect on experience. This ability will enable the person to manage eventualities in a specific situation, and his/her own actions and thinking in a criticalanalytical way. The described integrated approaches of clinical teaching, assessment and evaluation are in line with the contemporary requirements of the outcomes-based education that encourages the facilitation of reflective thinking of learners in clinical nursing education.

\section{CONCLUSION}

The described findings of nurse educator's perceptions on facilitating reflective thinking in clinical nursing education revealed various teaching strategies, assessment and evaluation methods with supportive attitudes that can facilitate reflective thinking through the three phases of reflective thinking as influenced by cognitive and affective thinking skills in their hierarchical order (see Figure 2). These teaching strategies, assessment and evaluation methods with the supporting attitudes should be fully conceptualised within the existing practice-oriented theories with the aim of describing the guidelines of how they should be implemented in clinical nursing education. It is recommended that action guidelines to facilitate reflective thinking through various teaching and evaluation methods be described to assist nurse educators and the nursing science community. Reflective thinking is viewed as a usable educational tool and is widely recognised as an effective and creative vehicle for lifelong learning and to improve practice.

\section{REFERENCES}

ATKINS, S \& MURPHY, K 1993: Reflections: A review of the literature. Journal of Advanced Nursing, (18):1188-1192.

AUSUBEL, DP 1968: Educational psychology: A cognitive view. London: Holt, Rinehart \& Winston.

BENNER, P 1982: From novice to expert. American Journal of Nursing, March:402-407.

BENNER, P; HOOPER-KYRIAKIDIS, P \& STANNARD, D 1999: Clinical wisdom and interventions in critical care. Philadelphia: WB Saunders.

BENNETT, JA 1995: "Methodological notes on empathy". Further consideration. Advanced Nursing Science, 18(1):36-50.

BEYER, BK 1988: Developing a thinking skill program. London: Allyn \& Bacon.

BIEHLER, RF \& SNOWMAN, J 1997: Psychology applied to teaching. New York: Houston Mifflin.

BLOOM, BS (ed) 1956: Taxonomy of educational objectives. The classification of educational goals. New York: McKay.

BOTES, AC 1995: The reconstruction of virtue-based ethics. RAU Cur Interdisciplinary Academic_Journal of Health, 1(2):1926.

CARL, AE 1995: Teacher empowerment through curriculum development. Theory into practice. Cape Town: Juta.

CHABELI, MM 1999: Perceptions of post-basic nursing students in the use of seminars as a teaching method. Curationis, December:69-74.

CHABELI, MM 2001: A model to facilitate reflective thinking in clinical nursing education. Johannesburg: Rand Afrikaans University ( $D$ Cur Thesis).

CONCISE OXFORD DICTIONARY 1995: Oxford: Clarendon.

DEITS, FE \& BURDEN, JJ 1980: An ABC of Biblical Exegesis. Pretoria: JL van Schaik.

DEMOCRATIC NURSING ORGANISATION OF SOUTH AFRICA (DENOSA) 1998: Ethical standards for nurse researchers. Position Paper. Pretoria: DENOSA.

DEPARTMENT OF NURSING, RAND AFRIKAANS UNIVERSITY 1999: Theory for health promotion in nursing. Department of Nursing. Johannesburg: Rand Afrikaans University.

DEWEY, J 1933: How to think. A restatement of the relation of 
reflective thinking to the educative process. Lexington, Massachusetts.

DUMINY, PA \& SÖHNGE, WF 1986: Didactics: Theory and practice. Cape Town: Maskew Miller Longman.

EWAN, C \& WHITE, R 1984: Teaching nursing. A self-instructional handbook. London: Croom Helm.

FACIONE, PA 1990: Critical thinking: A statement of expert consensus for the purpose of educational assessment and instruction. Executive Summary. Delphi Report. California: The California Academic Press.

GIFT, AG 1997: Clarifying concepts in nursing research. Pennsylvania: Springer.

GLEN, S; CLARK, A \& NICOL, M 1995: Reflecting on reflection: A personal encounter. Nurse Education Today, 15(1).

GRAVETT, S 1995: The assessment of learning: Guidelines and methods. Bureau for University Education Internal Publication, BUE (36). Johannesburg: Rand Afrikaans University. GRAVETT, S 1996: Instruction to promote effective learning. Bureau for University Education Internal Publication, BUE (35). Johannesburg: Rand Afrikaans University.

HEIDGERKEN, LE 1946: Teaching in schools of nursing. London: JB Lippincott.

JARVIS, P 1987: Adult learning in the social context. London: Croom Helm.

JENKINSON, TP 1997: Adolescents as reflective practitioners: Implications for nurse education. Nurse Education Today, 17:5861.

KNOWLES, M 1980: The modern practice of adult education: From pedagogy to andragogy. New York: Adult Company.

KRUEGER, RA 1994: Focus groups: A practical guide for applied research. London: Sage.

LINCOLN, YS \& GUBA, EG 1985: Naturalistic inquiry. London: Sage. LINDSEY, E \& HARTRICK, G 1996: Health promoting nursing practice: The demise of the nursing process? Journal of Advanced Nursing, 23:106-112.

LITTLE OXFORD DICTIONARY 1986: Oxford: Clarendon.

MAJOR, C \& PINES, R 1999: Teaching to learn. Washington DC: National Education Association.

McALLISTER, M 1996: Learning contracts: An Australian experience. Nurse Education Today, 16:199-205.

MELLISH, JM; BRINK, HIL \& PATON, F 1998: Teaching and learning the practice of nursing. Johannesburg: Heinemann.

MILES, MB \& HUBERMAN, AM 1994: Qualitative data analysis. London: Sage.

MILLER, MA 1992: Outcomes evaluation: measuring critical thinking. Journal of Advanced Nursing, 17:1401-1407.

MORSE, J 1994: Critical issues in qualitative research methods. London: Sage.

MOUTON, J 1996: Understanding social research. Pretoria: JL van Schaik.

MOUTON, J \& MARAIS, HC 1990: Basic concepts in the methodology of the social sciences. Pretoria: Human Science Research Council.

PAUW, DA 1993: Die ideale dosent. Bulletin vir Dosente. Blad vir Hoër Onderwys, 25(1):25-26. Johannesburg: Randse Afrikaanse Universiteit.

QUINN, FM 1988: The principle and practice of nurse education. London: Croon Helm.

PIETROFESSA, JJ; HOFFMAN, A; SPLETE, HH \& PINTO, DV 1978: Counselling: Theory, research and practice. Chicago: Rand McNally.

ROGET, P 1991: Roget's Thesaurus of English words and phrases. London: Dent.

SCHON, DA 1991: The reflective practitioner. How professionals think and act. Avebury: Aldershot.

SHIELDS, E 1995: Reflection and learning in student nurse. Nurse Education Today, 15(6).

THOMSON, S \& JOLLEY, M 1997: Nurse teachers as researchers. A reflective approach. New York: Arnold.

VAN DER HORST, H \& McDONALD, R 1997: Outcomes-based education. A teacher's manual. Pretoria: Kagiso.

VAN DER STOEP, F \& LOUW, WJ 1984: Didactics. Pretoria: Academia.

VAN HOOZER, HL; BRATTON, BD; OSTMOE, PM; WEINHOLTZ, D; CRAFT, MJ; GJERDE, CL \& ALBANESE, MA 1987: The teaching process. Theory and practice in nursing. Norwalk: AppletonCentury-Crofts.

WILSON, J 1963: Thinking with concepts. Cambridge: Cambridge University Press.

WOOLFOLK, AE 1990: Educational psychology. New Jersey: Prentice-Hall. 